\title{
Citizen Attention Web Application for the Municipality of Sabinas, Coahila, Mexico
}

\author{
Griselda Cortes ${ }^{1}$, Alicia Valdez ${ }^{2}$, Laura Vazquez ${ }^{3}$, Alma Dominguez $^{4}$ \\ Cesar Gonzalez ${ }^{5}$, Ernestina Leija ${ }^{6}$, Jose Cendejas $^{7}$ \\ Autonomous University of Coahuila, Coahuila, Mexico ${ }^{1,2,3,4,5}$ \\ Technological Institute of Superior Studies of the Carboniferous Region, Coahuila, Mexico ${ }^{6}$ \\ Technology University of Morelia, Michoacan, Mexico
}

\begin{abstract}
The information systems are fundamental to perform the daily activities of any organization. There is an increasing dependence on organizations to use information technology to achieve their objectives. This article presents the web information system that has been developed and implemented as support to manage the administrative services needs required by the citizens of the municipality of Sabinas Coahuila, México, seeking to be served in the best way and to obtain information from Faster and reliable way to follow up. Previously we worked manually, keeping the records in a format in Microsoft Excel. For the development of the system the agile XP methodology was used. The creation of the database was in MySQL and the development in Visual Studio 2015, the part of web programming in ASP .NET and programming in C \#. With the implementation of the system, there is currently electronic control of the requests made by citizens, providing integrity, availability and confidentiality of information; at the same time, streamlining the process of capturing and receiving applications in each department of the municipality of Sabinas, Coahuila, Mexico. In addition, the system provides statistics of the requests that were attended, those that are in process and those that were not attended.
\end{abstract}

\section{Keywords-Web system; citizen attention; database}

\section{INTRODUCTION}

Information systems offer improvements in all organizations, they help in decision-making and provide competitive advantages. In addition, they increase the organization capacity of a company.

The purpose of this article is to show the web information system that was developed and implemented as a support to manage the service requests required by the citizens of the municipality of Sabinas, Coahuila, Mexico, seeking to be served as best as possible and to obtain the information in a quicker and more reliable way for follow-up.

The function of an information system in an organization is to deliver timely and accurate information, with the appropriate presentation and formats, to the people who need it within the organization to decide or perform any operation at the time they need to have such information $[1,2]$.

Mexican municipal governments, they have among their administrative activities to offer public services of potable water, drainage, sewerage, treatment and disposal of wastewater, public lighting, collection, transfer, treatment and final disposal of urban waste, public safety, transit and transport, public works, etc. [3,4] cited in [5,6].

Next, the process that was carried out in the single window of the presidency of the municipality of Sabinas Coahuila, Mexico is described. Every day requests are received from citizens, asking for lamp changes, cutting of trees, scholarships for studies, paving of streets, repair of sewers, etc.

The areas involved in resolving what the citizen requires are located in different buildings and the applications are received in the single window area located in the municipal presidency. These requests are made personally by the citizen or can be made by phone calls which were registered in a format made in Microsoft Excel. Fig. 1 shows the format in which the control of the requests was kept until there was availability of personnel to indicate the pending to each area or department, which caused a delay in the solution of the citizen's requests.

Some of the problems that were presented in the process of citizen care were the following:

- The requests received by the citizens were registered in a single computer, which meant that they were not channeled and reported on time to the agency in charge.

- To respond the petition requested by the citizens, it took up to two days after for the request to arrive at the unit to which it belongs.

- It was difficult to make reports of the requests that were presented in the department of attention to the citizen, because this information was in each unit and this was not reported periodically to the department of citizen attention. Due to this situation it was difficult to know how many requests were attended, how many requests were in process and how many requests were not attended

- The information was not updated, so it was impossible for the citizen to be aware of the progress or status of their request.

As described above it is pertinent the development and implementation of a web system to solve the problems that arise in the public administration of the municipality of Sabinas, Coahuila, México. 


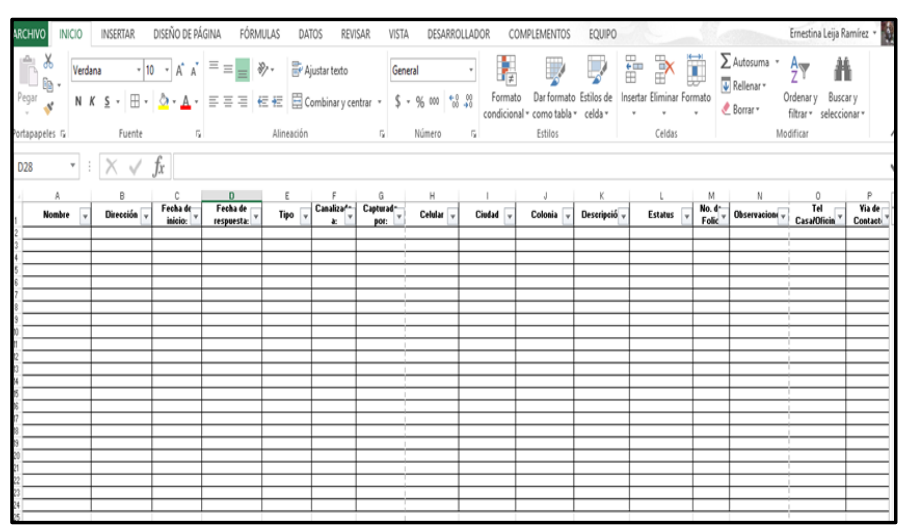

Fig. 1. Request Control Format.

With the development of this system will have the main characteristics of information, such as integrity, availability and confidentiality. In addition, the system will facilitate the storage and management of information.

The system will allow having control of the requests made by the citizens, having as benefit the mobilization in the process of capture and reception of the requests in each department of the municipality of Sabinas, Coahuila, México.

The system provides statistics of the requests that have already been attended, those that are in process and those that were not attended.

By automating the process, you will also have the benefit that the capture of the requests can be done from other buildings, always integrating the information in the same system.

In the first part of the article an introduction is presented, later theoretical foundations, methodology of system development, results, conclusions and finally the references.

\section{THEORETICAL FUNDAMENTAL}

\section{A. Software Engineering}

According to Rubio, Valencia, Peña and Rodríguez $[7,8]$ cited in $[9,10]$, technology is defined as "the means through which scientific knowledge is transferred to the solution of concrete problems in an effective manner".

García [11,12] cited in [13] states that software engineering is defined as a technological and management discipline related to the creation and maintenance of high-quality software products, developed on time and at minimum cost.

Software engineering is an engineering discipline that is interested in the production of software, from the specification of the system to its maintenance after it is put into operation. Software engineering has a systematic approach and considers the cost, time, reliability and customer needs $[14,15]$.

Every software development process focuses on the technical aspects such as the specification, development, validation and evolution of the software providing transparency and flexibility $[16,17]$.

\section{B. Web Applications}

On the other hand Arroyo, Rico, Barrón and Aguirre $[18,19]$ cited in $[3,4]$, comment that web applications automate part of the administrative activities, storing and organizing information in such a way that efficient searches and concrete reports can be carried out according to the needs of each of the profiles, as well as providing the benefit of access to timely information from anywhere.

Redrován, Loja, Correa and Piña [20,21] cited in [22,23], they define as a web application all software that allows to be processed and stored within web servers and then accessed via browsers.

The common feature of web applications is to centralize the software to facilitate the maintenance and updating of the systems. This way you avoid having copies of the applications in all the workstations, facilitating the updates and ensuring that the web application works correctly [24,25].

According to Pressman [26,27], most web applications have the following characteristics:

- They are in a network and must meet the needs of several clients.

- It can be accessed by several users at the same time.

- The number of users of the application varies from day to day.

- The user of the application should not wait too long to access the client part of the system.

- The main function of many web applications is to show the end user the content of their information in the form of text, audio, video or graphics.

- The aesthetic presentation and quality of the information are very important.

- Web applications must be continually updated.

- They must reach the market quickly.

- Security measures must be taken as they are available for access via a network.

\section{Agile Methodologies}

In 2001, the manifesto for the agile development of software is signed. This manifesto arises from the collaborative work of 17 important software developers [16,17].

This manifesto expresses that new ways of developing software have been discovered, due to their experience and with the help they have provided to third parties, where they have learned to appreciate the following:

- Individuals and interactions about processes and tools.

- Software running on extensive documentation.

- Collaboration with the client on contractual negotiation.

- Response to change about following a plan [28]. 
The goal of agile models is not to solve the challenges of software engineering; however, it seeks to provide a better development environment. Practitioners of these methodologies comment that they are the ones that best adapt to the constantly changing needs of business.

Agile models make use of user stories to capture the client's needs in a software project, they are written in simple language which helps communication between the client and the development team $[16,17]$.

Agile methodologies are identified by iterative development, simplicity in implementation, frequent deliveries and prioritization of requirements, customer-dependent development features, and cooperation between developers and customers. Agile methodologies consider requirements to change during the development process $[29,30]$.

\section{Extreme Programming XP}

The extreme programming is one of the methodologies of agile development of wide used software. The success is due that first we consider the satisfaction of the client, delivering the software according to their necessities, where the cooperative work is relevant with the client and the team of development.

Every project of software that is developed through this methodology considers essentially the communication, simplicity, feedback, respect and courage. The extreme programmers are in constant communication with their clients and programmers colleges, they accept commentaries at the moment to try their software since the first day, they deliver the system to the clients as soon as possible and they do the required changes [31].

\section{MethodOLOGY}

XP agile methodology was used for the development of the system. XP is an agile methodology that is based on customer satisfaction, so there must be a fluent communication between the client and the development team.

Fig. 2 details the process for developing the web system. It began with visits to the citizen attention department to clarify the requirements of the system and have a general vision of what was needed.

This was documented as the specification of software requirements based on the IEEE 830 standard. Subsequently, other visits were made to the client for the realization of user stories, which were performed between the client and the development team. In each story the acceptance criteria were specified.

Once the user stories were elaborated, they were sorted by priority and the iterations were organized in order to start with the development.
When starting with the iteration simple designs were made always thinking that the design should be able to adapt to probable changes that the client requests.

For the coding it started with the creation of the database in MySQL and the development in Visual Studio 2015, the part of the web programming in ASP.NET and the programming in C\#.

It was established what should be tested during the development and the programming was applied in pairs, remembering the recommendation that one programmer be the main programmer and the other focus on the quality of the software.

During the iteration development the team did the code tests, the modules integration tests and the client proved that the module will perform what he requested. When the client detected a failure, user histories were re-created or those that already existed were modified and reprogramming of the iterations was necessary.

At the end of each iteration, the process is started again, and it is repeated until the development of all the iterations is finished, resulting in the final system, which will be hosted on the contracted server.

Among the main features of the application is to ensure confidentiality, integrity, availability of information through the password assigned to authorized personal for accessing the system.

Fig. 3 shows the relational model, which shows the relationships between the tables in the database.

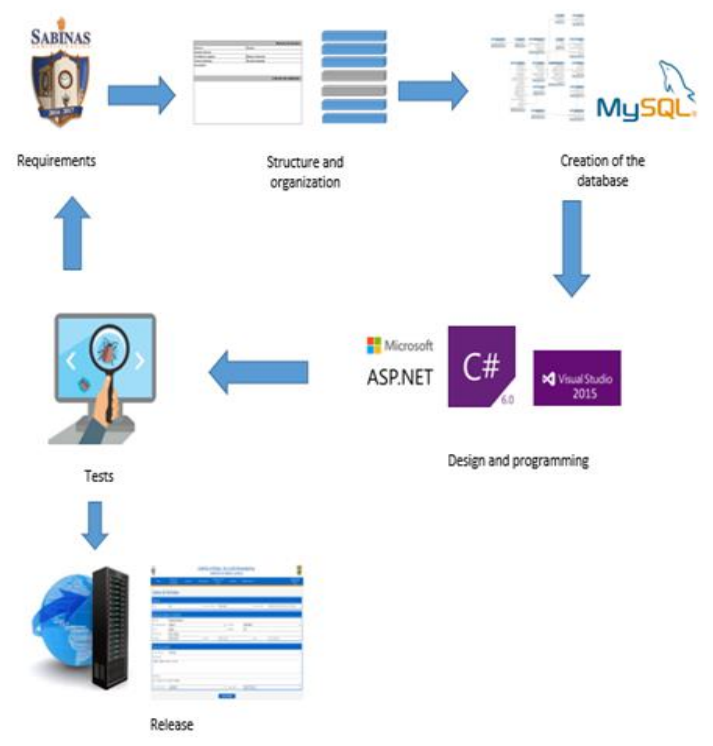

Fig. 2. Application Development Process. 


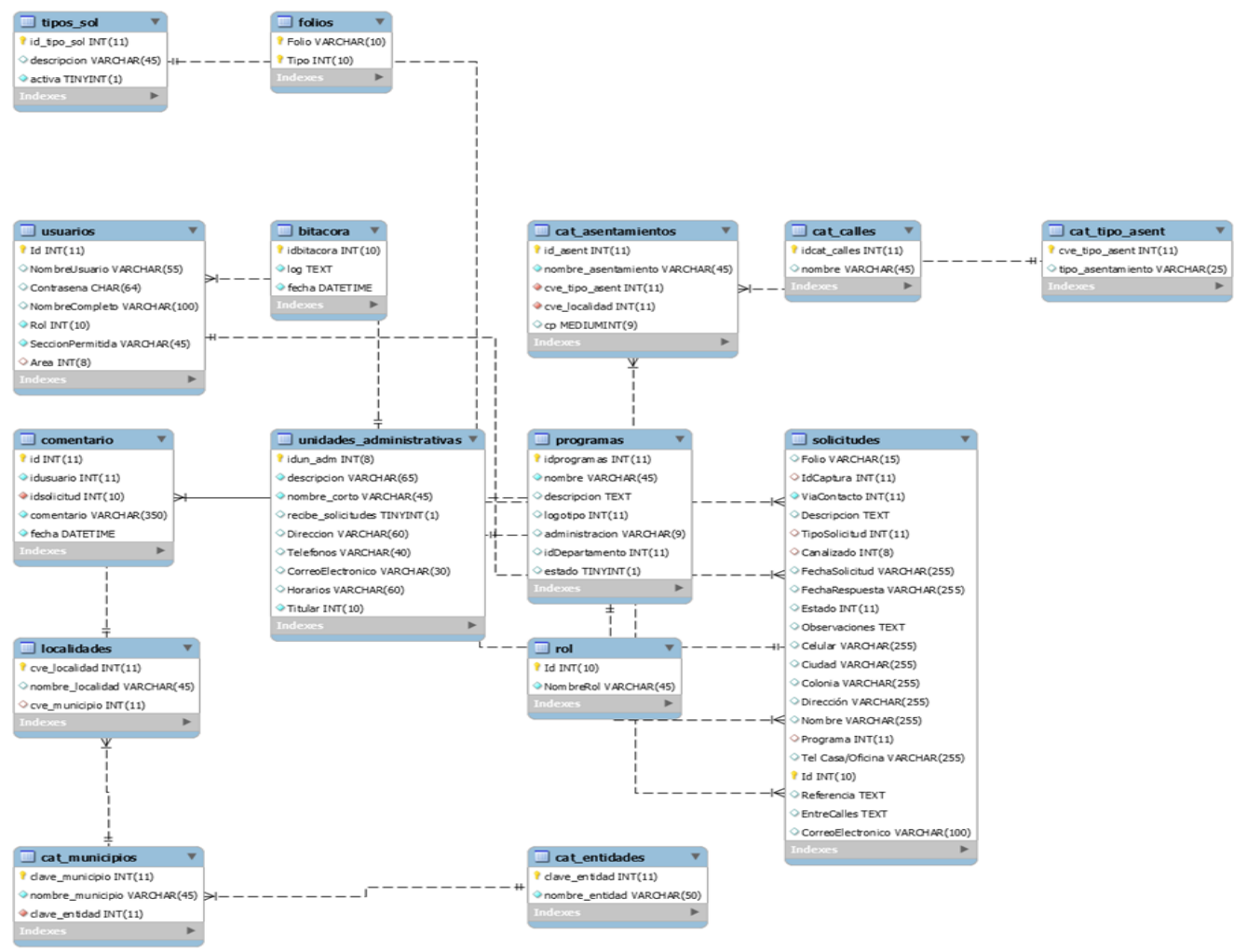

Fig. 3. Relational Model of the Database.

Table 1 shows one of the user stories, to start the development of the system.

TABLE. I. USER STORY ONE

\begin{tabular}{|c|c|c|c|c|}
\hline \multicolumn{5}{|l|}{ Historia de Usuario } \\
\hline Número: & 1 & \multicolumn{2}{|c|}{ Usuario: } & Administrador \\
\hline \multicolumn{2}{|l|}{ Nombre historia: } & \multicolumn{3}{|c|}{ Agregar usuario } \\
\hline \multicolumn{2}{|c|}{ Prioridad en negocio: } & Alta & $\begin{array}{l}\text { Riesgo en } \\
\text { desarrollo: }\end{array}$ & Alto \\
\hline Puntos estimados: & 100 & \multicolumn{2}{|c|}{ Iteración asignada: } & 1 \\
\hline \multicolumn{5}{|l|}{ Descripción: } \\
\hline \multicolumn{5}{|c|}{ Como administrador deseo poder agregar usuarios } \\
\hline \multicolumn{5}{|c|}{ Criterios de validación } \\
\hline \multicolumn{5}{|c|}{ a. Los campos no deben estar vacíos. } \\
\hline \multicolumn{5}{|c|}{$\begin{array}{l}\text { b. El área puede ser cualquiera de las siguientes: contraloría municipal, DIF } \\
\text { municipal, dirección de comunicación social, dirección de desarrollo } \\
\text { económico, dirección de desarrollo humano, dirección de desarrollo rural y } \\
\text { medio ambiente, dirección de ecologia, dirección de prevención y seguridad } \\
\text { ciudadana, dirección de servicios públicos, dirección de urbanismo y } \\
\text { ordenamiento dirección territorial, dirección técnica de planeación, presidente } \\
\text { municipal, secretaría de participación ciudadana, y ordenamiento terri- } \\
\text { secretaría del ayuntamiento, SIMAS o tesorería municipal. }\end{array}$} \\
\hline \multicolumn{5}{|c|}{ c. Los roles son administrador o departamento. } \\
\hline \multicolumn{5}{|c|}{$\begin{array}{l}\text { d. La contraseña se debe introducir dos veces para verificar que sea } \\
\text { correcta. }\end{array}$} \\
\hline
\end{tabular}

Fig. 4 and Fig. 5 show some of the screens that were designed in Pencil Software, to show them to the user, and make the necessary modifications before starting with the programming of the system.

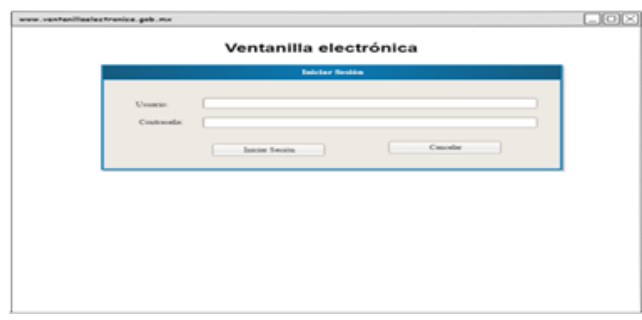

Fig. 4. Login Screen.

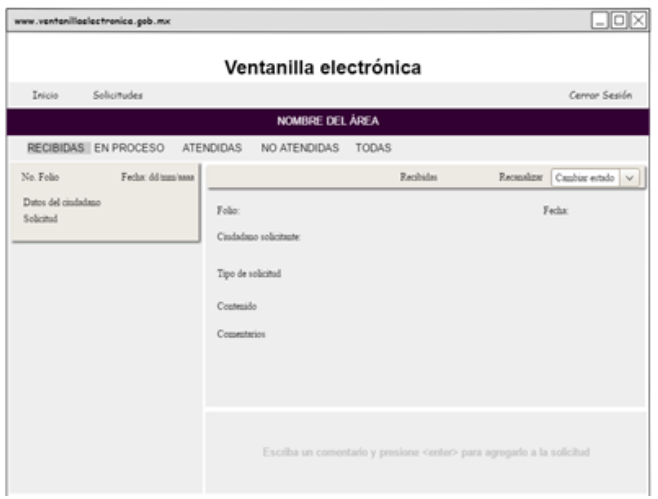

Fig. 5. Administrator Input Tray Screen. 


\section{RESUlTS}

The developed system was integrated as a module of the system of integral control of the municipal management inside of the option of the citizen attention. Following we show some relevant screens of the system.

To have access as an administrator, first, it is necessary to access the municipality's website. In the upper right side, you can see the section to log in as shown in Fig. 6.

Is necessary to introduce the user, the password and lately click the button to enter. It is necessary to validate the user and the passwords that are in the data base, in the other side emit a message and do not allow the access.

Once the system is accessed it takes you to the inbox of the administrator as shown in Fig.7. On this screen, the status of the requests that reach the department is listed.

As previously mentioned, the system was integrated as a module of the system of integral control of the municipal management inside of the option of the citizen attention. This can be seen in the Fig.8.

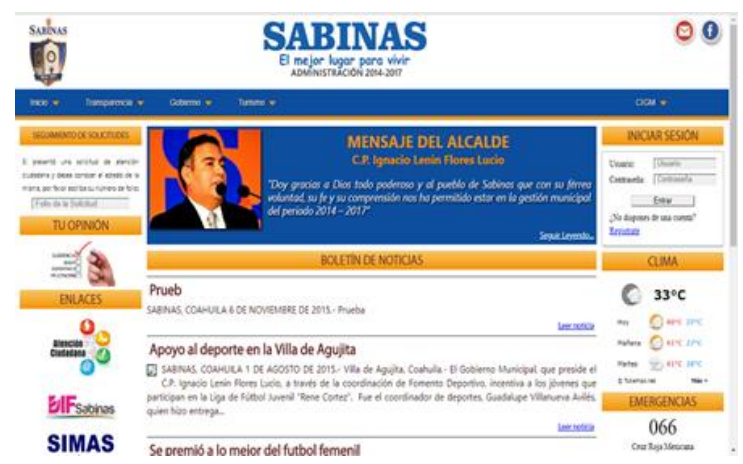

Fig. 6. Login Screen.

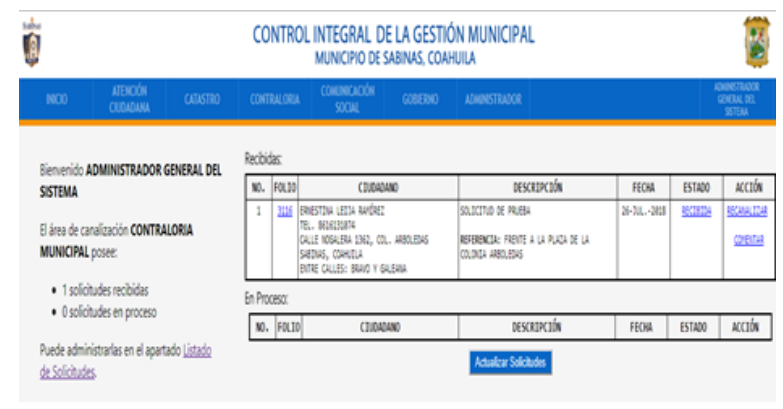

Fig. 7. Inbox Screen Administrator.

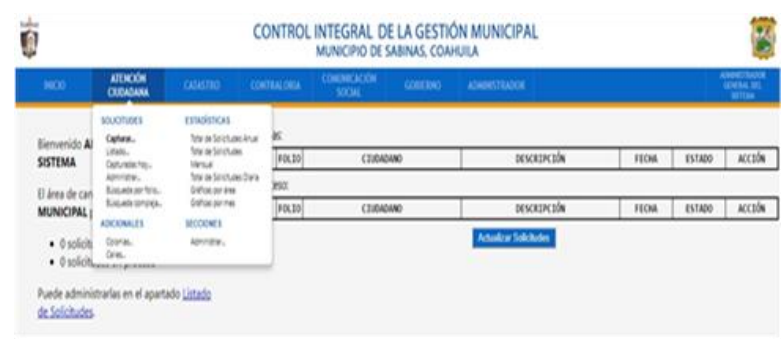

Fig. 8. Citizen Attention Module Menu Screen.
As department, you have the option to change the status of the received requests to in process; If the requests are already in process you can change their status to completed or unfinished and add a comment. If requests arrived in the inbox that do not correspond to the department, the administrator can reanalyze the requests to the corresponding department. When done, the request disappears from the administrator's inbox and appears in the inbox of the department or area that was selected. The Update Requests button will be clicked each time the administrator wants to see if new requests arrived.

Fig. 9 shows the capture of the requests; the folio is automatically assigned as well as the date and the user that captures.

When capturing the data of the citizen or institution that makes the request, the city can be selected from a list of populations that are already captured. When the city is selected the corresponding neighborhoods are activated to choose the one of the citizen.

In the data of the request the contact way can be: personal, telephone, SMS, web, e-mail or others.

The type of request and channeling is selected from the list of options that are already captured within the system.

The system allows searching by name of the citizen, colony, city or town, street or telephoning so that if the administrator wants to know all the requests received from a particular neighborhood or a citizen, here you can get the information.

As can be seen in Fig. 9 the search criteria are written and then the button "Show requests" is clicked to show the requests that meet the criteria. Again the folios of the applications appear as a link, so that if you want more information of any of them it will be enough to select the folio.

The system allows the administrator to view the statistics of the requests by day, month and year. Figure 10 shows the statistics by year.

In addition, the administrator can view the graphs of the requests by area and by month. In both, the pipeline area is selected, as well as a start date and a finish date for the charts. This is shown in Fig. 11.

The system allows the citizen to follow up on his request by accessing the municipality's website. Within the web page, in the upper left part you must write the folio of your application and then press enter, this is shown in Fig. 6.

The limitations presented by the project are those of the infrastructure, since being a System that will be used through the internet, it is necessary that you always have access to the same; If at any time there is no internet, you will not have access to the system.

Another limitation is that, being a web-based system, it is necessary to hire a service Web hosting so you will have to make a payment by the municipality, this could be considered as limiting since the payment is annual. 


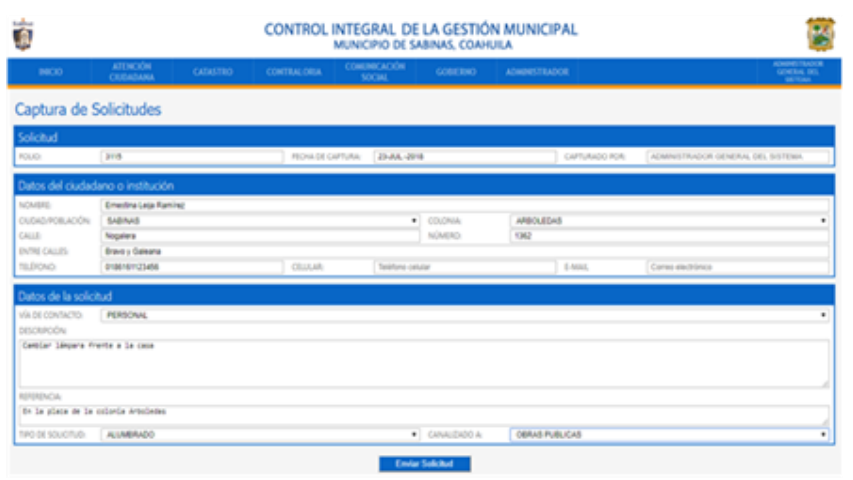

Fig. 9. Requested Capture Screen.

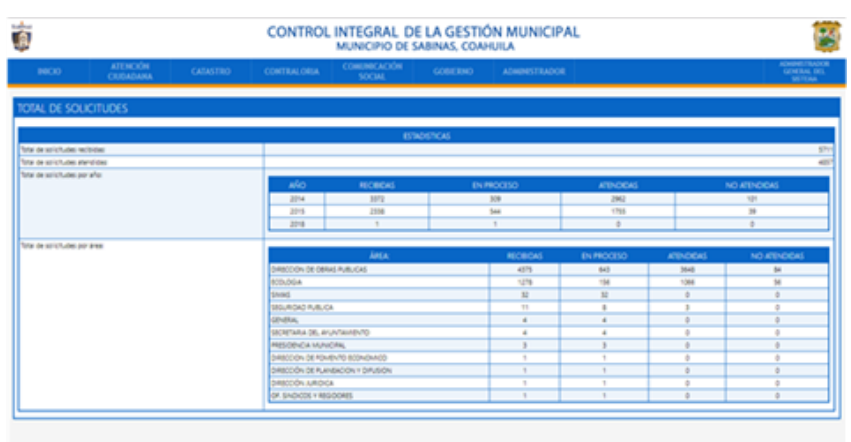

Fig. 10. Screen to Show the Total of the Annual Requests.

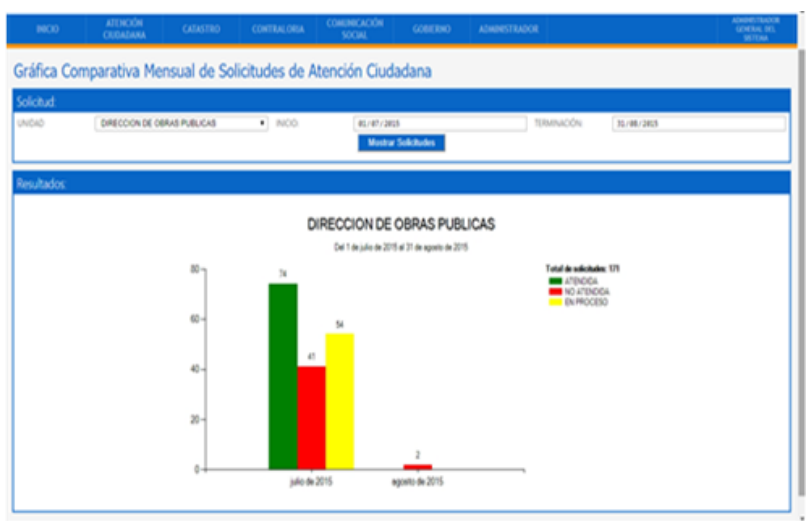

Fig. 11. Monthly Comparative Graph of the Requests.

One more limitation that could be observed when the system was implemented in the municipality of San Juan de Sabinas Coahuila, Mexico is the resistance to use it by the personnel involved because although they were given training for their use in the end not all used.

\section{CONCLUSION}

The system was developed for the 2014-2017 administration and was successfully implemented in the municipality of Sabinas, Coahuila, Mexico. With its implementation, it is possible to have $100 \%$ control of the applications submitted by citizens.

The system provides the statistics of the requests received, in process, attended and not attended. These are obtained at the time the option is selected and provides the updated information.
The system was also offered to the municipality of San Juan de Sabinas, Coahuila, Mexico and was accepted. In this municipality, the system was installed as an Electronic Window, changing only the colors and logos of the system according to their requirements.

The system has the main characteristics of the information, such as integrity, availability and confidentiality.

It is important to mention that the system finished its function with the 2017 administration. However, it was submitted to the current administration 2019-2021 and was approved, so the necessary changes were made according to the new dependency requirements.

Each system has an opportunity for improvement; in this case the improvements that will be made are adding the CRUDs (Create, Read, Update and Delete) in the pipeline areas and locations. He will make adjustments to its architecture, removing some fields from the database that are not required.

\section{DISCUSSION}

The system developed and implemented has been of great help in decreasing the time in sending the requests to each department involved and in generating the statistics for the report of the work performed.

However, for the system to produce the correct results, it is necessary that all personnel is involved in the use of it. In addition, he agrees to feed him with the follow-up of each request changing its status to in process, attended or not attended, since from there the statistics will be obtained.

On the other hand to be a system for a municipality, when the management of each administration ends it has been necessary to offer the incoming administration the use of the software and explain its functioning.

It is relevant to mention that there was no instrument for measuring the system as such since an agile methodology was used for its development. He was interacting with the person who requested the development of the system once a week reviewing what was scheduled and she is determined if it was really needed.

When releasing the system the same person was informing its use and some adjustments that were made to do, the subsequent administration was very enthusiastic about the software and they decided to continue using it, adapting the colors and logos of the new administration.

\section{REFERENCES}

[1] A. Gómez and C. Suárez. Information systems: practical tools for management, 2010. Mexico: Alfaomega Editor Group.

[2] A. Gómez y C. Suárez . Sistemas de información: herramientas prácticas para la gestión, 2010. México: Grupo Editor Alfaomega.

[3] R. Silva, E. Cruz, I. Méndez and J. Hernández. . Digital Management System to improve the administrative processes of Higher Education Institutions: Case study at the Universidad Autónoma Metropolitana. Educational Perspective, Teacher Training, 2013. 52 (2), pp. 104-134.

[4] R. Silva, E. Cruz, I. Méndez y J. Hernández. Sistema de Gestión Digital para mejorar los procesos administrativos de Instituciones de Educación Superior: Caso de estudio en la Universidad Autónoma Metropolitana. Perspectiva Educacional, Formación de Profesores, 2013. 52 (2), pp. 104-134. 
[5] National Institute of Public Administration A.C. (INAP). Municipal technical guidelines, Mexico City, National Institute of Public Administration A.C. 2009. Retrieved from: http://www.inafed.gob.mx/work/models/inafed/Resource/322/1/images/ guias_inap.pdf

[6] Instituto Nacional de Administración Pública A.C. (INAP). Guías técnicas municipales, Ciudad de México, Instituto Nacional de Administración Pública A.C. 2009. Recuperado de: http://www.inafed.gob.mx/work/models/inafed/Resource/322/1/images/ guias_inap.pdf

[7] R. Rubio Núñez, L. Valencia Pérez, M. Peña Cheng and E. Rodríguez Muñoz. Importance of Technological Management in the Mexican Municipal Governments. Management of people and technology magazine, 2018. 33, pp. 55-67.

[8] R. Rubio Núñez, L. Valencia Pérez, M. Peña Cheng y E. Rodríguez Muñoz. Importancia de la Gestión Tecnológica en los Gobiernos Municipales Mexicanos. Revista gestión de las personas y tecnología, 2018. 33, pp. 55-67.

[9] S. Ortiz Cantú and A. Pedroza Zapata. What is the Management of Innovation and Technology (GInnT) ?. Journal of Technology Management and Innovation, 2006.

[10] S. Ortiz Cantú y A. Pedroza Zapata. ¿Qué es la Gestión de la Innovación y la Tecnología (GInnT)? Journal of Technology Management and Innovation, 2006. 1 (2), pp. 64-82.

[11] J. García Peñalvo. Software engineering. In Teaching and Research Project, 2018. Editorial University of Salamanca. Grail Group.

[12] J. García Peñalvo. Ingeniería de software. En Proyecto Docente e Investigador, 2018. Editorial Universidad de Salamanca. Grupo Grial.

[13] W.B. Frakes, C. Fox y B. A. Nejmeh. Software Engineering in the UNIX/C Environment. Englewood Cliffs, 1991. NJ, USA: Prentice Hall.

[14] I. Sommerville. Software Engineering. Ninth edition, 2011. Mexico, Pearson.

[15] I. Sommerville. Ingeniería de Software. Novena edición, 2011. México, Pearson.

[16] D. Ramos, R. Noriega, J. Laínez and A. Durango. Course in software engineering. 2nd edition, 2017. ITcampus Academy.

[17] D. Ramos, R. Noriega, J. Laínez y A. Durango. Curso de ingeniería de software. $2^{\mathrm{a}}$ edición, 2017. ITcampus Academy.

[18] M. Arroyo, J. Rico, J. Barrón and J. Aguirre. Web administration system of documentary evidence for accrediting bodies. Journal of scientific and technical application, 2015.1 (1), pp.54-65.
[19] M. Arroyo, J. Rico, J. Barrón y J. Aguirre. Sistema de administración web de evidencias documentales para organismos acreditadores. Revista de aplicación científica y técnica. 2015. 1 (1), pp. 54-65.

[20] F. Redrován Castillo, N. Loja Mora, K. Correa Elizades and J. Piña Orozco. Comparison of quality metrics for the development of web applications. 3C Technology. Glosas de Innovación applied to the SME, 2018. 7 (3), pp. 94-113. Retrieved from: DOI: http://dx.doi.org/10.17993/3ctecno.2018.v7n3e27.94-113/

[21] F. Redrován Castillo, N. Loja Mora, K. Correa Elizades y J. Piña Orozco. Comparación de métricas de calidad para el desarrollo de aplicaciones web. 3C Tecnología. Glosas de Innovación aplicadas a la pyme, 2018. 7(3), pp. 94-113. Recuperado de: DOI: http://dx.doi.org/10.17993/3ctecno.2018.v7n3e27.94-113/

[22] A. Ramos Martin and M. Ramos Martin. Web applications. Second Edition, 2014. Madrid, Spain: Auditorium.

[23] A. Ramos Martin y M. Ramos Martin. Aplicaciones Web. Segunda Edición, 2014. Madrid, España: Paraninfo.

[24] F. Berzal, F. Cortijo and J. Cubero. Professional development of web applications with ASP.NET, 2007. Editor Ikor Consulting.

[25] F. Berzal, F. Cortijo y J. Cubero. Desarrollo profesional de aplicaciones web con ASP.NET, 2007. Editor Ikor Consulting.

[26] R. Pressman. Software engineering a practical approach. Seventh edition, 2010. Editorial Mc. Graw Hill.

[27] R. Pressman. Ingeniería de software un enfoque práctico. Séptima edición, 2010. Editorial Mc. Graw Hill.

[28] K. Beck, M. Beedle, A. Bennekum, A. Cockburn, W. Cunningham, M. Fowler, J. Grenning, J. Highsmith, A. Hunt, R. Jeffries, J. Kern, B. Marick, R. Martin, S. Mellor, K. Schwaber, J. Sutherland and D. Thomas, 2001. Retrieved from: http://scrummethodology.com/the-agilemanifesto-and-twelve-principles/

[29] A. Navarro Cadavid, J. Fernández Martínez and J. Morales Vélez. Review of agile methodologies for software development. Prospective, 2013. 11 (2), pp. 30-39.

[30] A. Navarro Cadavid, J. Fernández Martínez y J. Morales Vélez. Revisión de metodologías ágiles para el desarrollo de software. Prospectiva, 2013. 11 (2), pp. 30-39.

[31] D.Wells. Extreme Programming: A gentle introduction, 2013. Retrieved from: http://www.extremeprogramming.org/ 